\title{
Hydro-geochemistry and application of water quality index (WQI) for groundwater quality assessment, Anna Nagar, part of Chennai City, Tamil Nadu, India
}

\author{
S. Krishna kumar • A. Logeshkumaran • \\ N. S. Magesh • Prince S. Godson • N. Chandrasekar
}

Received: 6 January 2014/ Accepted: 22 April 2014/Published online: 24 May 2014

(c) The Author(s) 2014. This article is published with open access at Springerlink.com

\begin{abstract}
In the present study, the geochemical characteristics of groundwater and drinking water quality has been studied. 24 groundwater samples were collected and analyzed for $\mathrm{pH}$, electrical conductivity, total dissolved solids, carbonate, bicarbonate, chloride, sulphate, nitrate, calcium, magnesium, sodium, potassium and total hardness. The results were evaluated and compared with WHO and BIS water quality standards. The studied results reveal that the groundwater is fresh to brackish and moderately high to hard in nature. $\mathrm{Na}$ and $\mathrm{Cl}$ are dominant ions among cations and anions. Chloride, calcium and magnesium ions are within the allowable limit except few samples. According to Gibbs diagram, the predominant samples fall in the rock-water interaction dominance and evaporation dominance field. The piper trilinear diagram shows that groundwater samples are $\mathrm{Na}-\mathrm{Cl}$ and mixed $\mathrm{CaMgCl}$ type. Based on the WQI results majority of the samples are
\end{abstract}

S. Krishna kumar $(\bowtie)$

Department of Geology, University of Madras, Guindy campus, Chennai 600025, Tamil Nadu, India

e-mail: coralkrishna@yahoo.co.in

\section{A. Logeshkumaran \\ Department of Civil Engineering, VKS College of Engineering and Technology, Desiyamagalam, Karur 639120, Tamil Nadu, India \\ e-mail: logucivil106@gmail.com}

N. S. Magesh · P. S. Godson · N. Chandrasekar

Centre for GeoTechnology, Manonmaniam Sundaranar

University, Tirunelveli 627 012, Tamil Nadu, India

e-mail: mageshissivan@gmail.com

P. S. Godson

e-mail: princegodsons@gmail.com

N. Chandrasekar

e-mail: profncsekar@gmail.com falling under excellent to good category and suitable for drinking water purposes.

Keywords Gibbs and Piper diagram - Groundwater quality · Anna Nagar · Part of Chennai city

\section{Introduction}

Ground water contamination in urban environment is a major issue and is complicated by large number of potential source of contamination (Jayaprakash et al. 2008). India has wide spectral variations of meteorological, topographical, geomorphological, hydrological, geological, and hydrogeological conditions. The chemistry of groundwater is an important factor determining its use for domestic, irrigation and industrial purposes. Utilization of land varies from place to place due to rapid urbanization and industrialization, without following the strict environmental norms, causing a lot of variation of quality of groundwater within a short distance, which constrains the developmental activities drastically everywhere (Subba Rao 1997, 2006). The urban aquifers are the only natural resource for drinking water supply, they are often perceived as of lesser relevance for the drinking water supply, leading to crisis in terms of drinking water scarcity, becoming increasingly polluted thereby decreasing their potability (Dixit et al. 2005; Tiwari et al. 2012). Once contamination of groundwater in aquifers occurs by means of industrial activities and urban development, it persists for hundreds of years because of very slow movement of water in them (Jerry 1986) and prompts investigations on their quality. The knowledge of hydrochemistry is important to assess the ground water quality in any area in which the ground water is used for both irrigation and drinking needs (Srinivas et al. 2013). The water quality 
assessment may give clear information about the subsurface geologic environments in which the water presents (Raju et al. 2011). The conventional techniques such as trilinear plots, statistical techniques are widely accepted methods to determine the quality of water. The problems of ground water quality are more acute in areas that are coastal, densely populated and thickly industrialized and have shallow groundwater tube wells (Ballukraya and Ravi 1999; Reddy and Subba Rao 2001; Malini et al. 2003; Krishna kumar et al. 2011; Padmalal et al. 2012; Bagyaraj et al. 2013; Selvam et al. 2013). The present study was carried out for qualitative analysis based on physico-chemical parameters of groundwater.

\section{Study area}

Chennai, formerly known as Madras, is the capital of the state of Tamil Nadu and India's fourth largest metropolitan city. The latitude of Chennai city is $13.04^{\circ} \mathrm{N}$ and longitude $80.17^{\circ} \mathrm{E}$. The city covers an area of $174 \mathrm{~km}^{2}$. The metropolitan area covers $1,177 \mathrm{~km}^{2}$. The city is divided into four major parts like North, Central, South and West regions. The northern localities are devoted for the automobile industries, other medium- and small-scale industries. The study area has unmatched importance as a commercial and residential area in West Chennai. The study area extends from $13^{\circ} 5^{\prime} 31^{\prime \prime}$ North to $80^{\circ} 11^{\prime} 57^{\prime \prime}$ East (Fig. 1). The population of the Chennai city is $8,917,749$ with a density of 26,702/ $\mathrm{km}^{2}$ (CDSH 2012).

The Northeast monsoon during the month of October, November and December chiefly contributes rainfall to the study area. Most of the precipitation occurs in the form of one or two cyclones caused due to depressions in Bay of Bengal. The average annual rainfall of the study area is 1,200 $\mathrm{mm}$. The Chennai district enjoys a tropical climate with a mean annual temperature of $24.3-32.9{ }^{\circ} \mathrm{C}$. The humidity is usually in the range of 6-84\%. Chennai is underlain by various geological formations from ancient Archaean to the Recent Alluvium. The geological formations can be grouped into three units, namely (1) the Archaean crystalline rocks, (2) consolidated Gondwana and Tertiary sediments, and (3) the Recent Alluvium. The study area chiefly consists of unconfined Tertiary sedimentary aquifers. The Archaean crystalline rocks comprise chiefly of Charnockites, gneisses and the associated basic and ultra basic intrusive. The alluvium consists of sand, silt
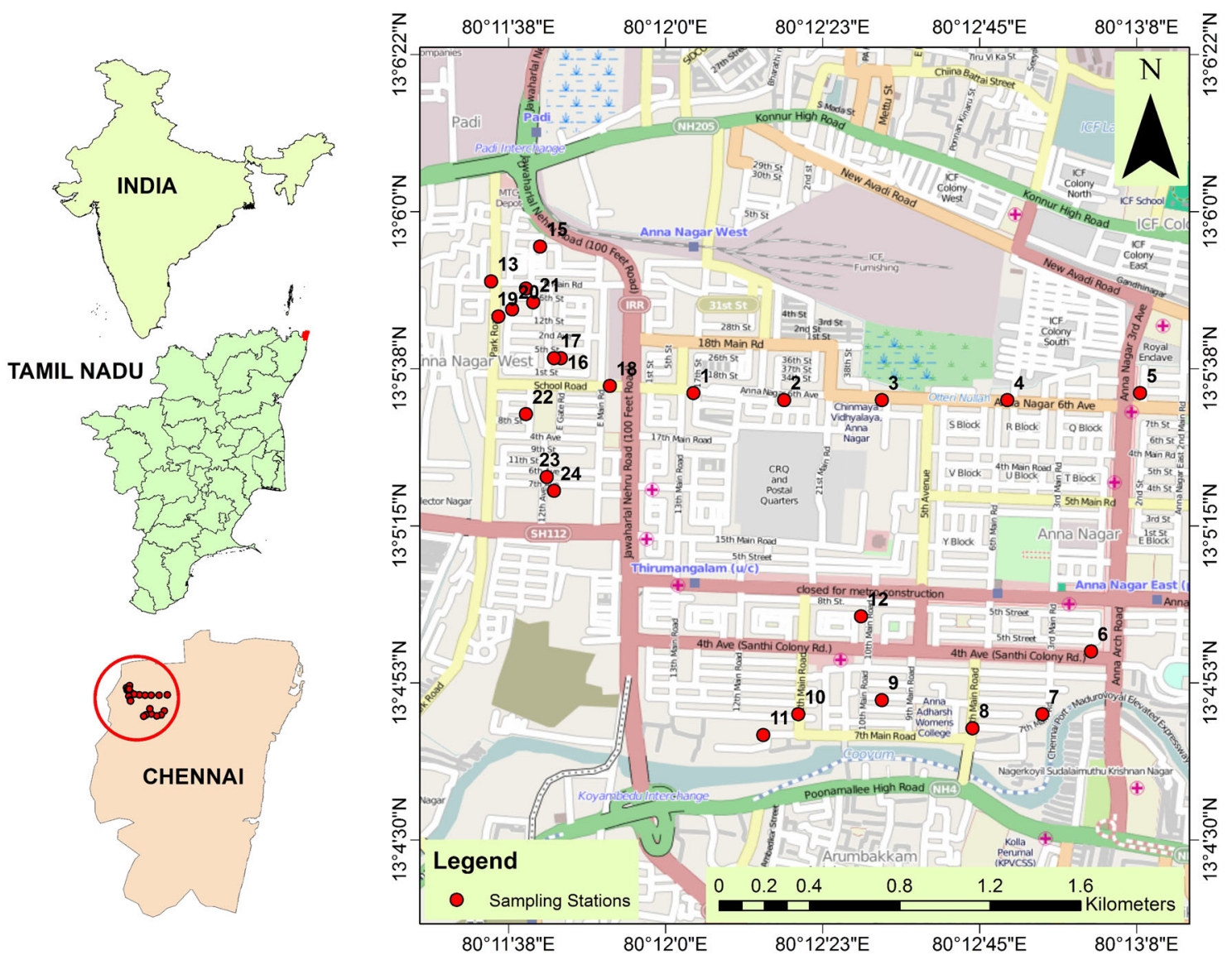

Fig. 1 Sampling location map of the study area 
and clays. The thickness of alluvium varies from place to place and a maximum of $28 \mathrm{~m}$ is encountered in north Chennai. The computed transmissivity varied between 6.00 and $872 \mathrm{~m}^{2} /$ day and the storativity varied between $2.9 \times 10^{-4}$ and $4.5 \times 10^{-3}$ (CGWB Technical Report 2008).

\section{Materials and methods}

Representative ground water samples were obtained from 24 bore wells selected on the basis of geographical variation, the depth ranges from $80-150 \mathrm{~m}$. The electrical conductivity, temperature and $\mathrm{pH}$ were measured in situ. Field measurements of $\mathrm{pH}$ and electrical conductivity (EC) were made using a handheld $\mathrm{pH}$ and EC meter (HANNA HI-9828, USA). Bicarbonate analysis was carried out using acid titration method; chloride concentration was measured by $\mathrm{AgNO}_{3}$ titration method; sulphate by $\mathrm{BaCl}_{3}$ turbidity method using a spectrophotometer. Sodium and potassium were analyzed using flame photometer; calcium and magnesium by the titration method. The analytical procedures are as suggested by the American Public Health Association (APHA 1995). The analytical precision and measurement reproducibility was less than $2 \%$. The ionic balance error for studied ions was within $\pm 5 \%$. The base map of the study area was prepared using the Survey of India topographic sheets and digitized using Arc GIS 9.3 software. Trimble ${ }^{\circledR}$ Recon GPS was used to find the location of each sampling site and the coordinates were imported to GIS platform for preparation of the base map. The geochemical results are plotted on piper trilinear plot using AquaChem 4.0 software and Gibbs diagram is plotted to assess the quality controlling mechanism and dominated hydro-geochemical facies of the study area. Statistical analysis was performed using SPSS software package (SPSS, 2001). The physico-chemical parameters of the analytical results of groundwater were compared with standard guideline values recommended by the WHO.

Water quality index calculation

The water quality index (WQI) was calculated for evaluating influence of natural and anthropogenic activities based on several key parameters of groundwater chemistry. To calculate the WQI, the weight has been assigned for the physico-chemical parameters according to the parameters relative importance in the overall quality of water for drinking water purposes. The assigned weight ranges from 1 to 5 . The maximum weight of 5 has been assigned for nitrate and TDS, 4 for $\mathrm{pH}, \mathrm{EC}, \mathrm{SO}_{4}, 3$ for $\mathrm{HCO}_{3}, \mathrm{Cl}, 2$ for $\mathrm{Ca}, \mathrm{Na}, \mathrm{K}$ and weight 1 assigned for magnesium (Vasanthavigar et al. 2010). The relative weight is computed from the following equation.
$W i=w i / \sum_{i=1}^{n} w i$

where

$W i$ is the relative weight

$w i$ is the weight of each parameter

$n$ is the number of parameters.

The quality rating scale for each parameter is calculated by dividing its concentration in each water sample by its respective standards (World Health Organization 2011) and multiplied the results by 100 .

$q i=(C i / S i) \times 100$,

where

$q i$ is the quality rating

$\mathrm{Ci}$ is the concentration of each chemical parameter in each sample in milligrams per liter

$\mathrm{Si}$ is the World Health Organization standard for each chemical parameter in milligrams per liter according to the guidelines of the (WHO 2011)

For computing the final stage of WQI, the SI is first determined for each parameter. The sum of SI values gives the water quality index for each sample.

$S I i=W i \times q i$

$W Q I=\sum S I i$,

where

SIi is the sub-index of $i$ th parameter

$q i$ is the rating based on concentration of $i$ th parameter $n$ is the number of parameters

\section{Results and discussion}

The statistical parameters like minimum, maximum and mean concentration of physico-chemical parameters, major ion concentrations are tabulated in Table 1.

Temperature and $\mathrm{pH}$

The temperature variation ranges from 26 to $27{ }^{\circ} \mathrm{C}$ with a mean value of $26.67{ }^{\circ} \mathrm{C}$. The $\mathrm{pH}$ indicates the strength of the water to react with the acidic or alkaline material present in the water. It controls by carbon dioxide, carbonate and bicarbonate equilibrium (Hem 1985). The combination of $\mathrm{CO}_{2}$ with water forms carbonic acid, which affects the $\mathrm{pH}$ of the water. The permissible limit of $\mathrm{pH}$ is $6.5-8.5$. The $\mathrm{pH}$ in the groundwater is varied from 6.0 to 8.2. This may be attributed to the anthropogenic activities like sewage disposal and improper irrigation process and weathering process in the study area. 
Table 1 Statistics of physico-chemical parameters, major ions $(n=24)$, World Health Organization (World Health Organization 2011) and Bureau of Indian Standards (BIS, 1991) for drinking waters of study area

\begin{tabular}{|c|c|c|c|c|c|}
\hline Parameters & Minimum & Maximum & Mean & $\begin{array}{l}\text { WHO } \\
\text { standard } \\
(2011)\end{array}$ & $\begin{array}{l}\text { BIS } \\
\text { standard } \\
(1991)\end{array}$ \\
\hline Temp $\left({ }^{\circ} \mathrm{C}\right)$ & $26^{\circ} \mathrm{C}$ & $27^{\circ} \mathrm{C}$ & $26.67^{\circ} \mathrm{C}$ & - & - \\
\hline pH (on scale) & 6 & 8.2 & 7.03 & $6.5-8.5$ & $6.5-8.5$ \\
\hline $\mathrm{EC}(\mu \mathrm{S} / \mathrm{cm})$ & 580 & 7,250 & 1,828 & 1,500 & - \\
\hline TDS (mg/l) & 373.5 & 4,669 & 1,177 & 500 & 500 \\
\hline $\mathrm{HCO}_{3}(\mathrm{mg} / \mathrm{l})$ & 18.3 & 359.9 & 165.7 & 500 & - \\
\hline $\mathrm{Cl}(\mathrm{mg} / \mathrm{l})$ & 115.21 & $2,011.8$ & 383.3 & 250 & 250 \\
\hline $\mathrm{SO}_{4}(\mathrm{mg} / \mathrm{l})$ & 22.2 & 98.6 & 53.9 & 250 & 200 \\
\hline $\mathrm{NO}_{3}(\mathrm{mg} / \mathrm{l})$ & 0.1 & 3.9 & 1.013 & 45 & 45 \\
\hline $\mathrm{Ca}^{2+}(\mathrm{mg} / \mathrm{l})$ & 26 & 130 & 53.5 & 75 & 75 \\
\hline $\mathrm{Mg}^{2+}(\mathrm{mg} / \mathrm{l})$ & 1.2 & 141.6 & 18.8 & 50 & 30 \\
\hline $\mathrm{Na}^{+}(\mathrm{mg} / \mathrm{l})$ & 71 & 1,200 & 258.9 & 200 & - \\
\hline $\mathrm{K}^{+}(\mathrm{mg} / \mathrm{l})$ & 3 & 36 & 9.33 & 12 & - \\
\hline $\mathrm{TH}(\mathrm{mg} / \mathrm{l})$ & 89.5 & 814.55 & 211.58 & - & - \\
\hline
\end{tabular}

Electrical conductivity (EC)

Electrical conductivity is a measure of water capacity to convey the electrical current. The most desirable limit of EC in drinking water is prescribed as $1,500 \mu \mathrm{S} / \mathrm{cm}$. The value of EC is between 580 and 7,250 $\mu \mathrm{S} / \mathrm{cm}$. EC measures the ability of a material to conduct an electric current such that the higher EC indicates enrichment of salts in the groundwater. Thus, the EC can be classified as type I, if the enrichments of salts are low (EC $<1,500 \mu \mathrm{S} / \mathrm{cm}$ ); type II, if the enrichment of salts are medium (EC: 1,500 and $3,000 \mu \mathrm{S} / \mathrm{cm}$ ); and type III, if the enrichments of salts are high (EC $>3,000 \mu \mathrm{S} / \mathrm{cm}$; Sarath Prasanth et al. 2012). According to the classification of EC, $63 \%$ of the total groundwater samples $(1,3-9,12,15,18,20-23)$ falling under the type I (low enrichment of salts), $25 \%$ of the samples $(13,14,16,17,19,24)$ under the type II (medium enrichment of salts), and $12 \%$ of the samples $(2,10,11)$ under the type III (high enrichment of salts).

\section{Total dissolved solids (TDS)}

Total dissolved salts in the groundwater is between 373.52 and 4,669 mg/l. Low TDS (373.52-895.16 mg/l) is observed in the samples $1,3-9,15,18$ and 23 which indicates the influence of rock-water interaction in relation to recharge water. The high TDS observed in the study area ranges from 959.56 to $4,669 \mathrm{mg} / \mathrm{l}$; the occurrence of high TDS is due to the influence of anthropogenic sources, such as domestic sewage, septic tanks and agricultural activities. According to WHO specification TDS up to $500 \mathrm{mg} / \mathrm{l}$ is the highest desirable and up to $1,500 \mathrm{mg} / \mathrm{l}$ is maximum permissible.

Degree of groundwater quality can be classified as fresh, if the TDS is less than $1,000 \mathrm{mg} / \mathrm{l}$; brackish, if the TDS is between 1,000 and $10,000 \mathrm{mg} / \mathrm{l}$; saline, if the TDS is varied from 10,000 to $1,000,000 \mathrm{mg} / \mathrm{l}$; and brine, if the TDS is more than $1,000,000 \mathrm{mg} / 1$ (Todd 1980). Accordingly, the quality of groundwater in the present study area is classified as fresh and brackish in 70 and $30 \%$ of the total water samples.

Bicarbonate $\left(\mathrm{HCO}_{3}\right)$

The concentration of carbonates in natural waters is a function of dissolved carbon dioxide, temperature, $\mathrm{pH}$, cations and other dissolved salts. Bicarbonate concentration of natural waters generally held within a moderate range by the effects of the carbonate equilibrium. Most surface streams contained less than $200 \mathrm{mg} / \mathrm{l}$ of carbonate and bicarbonate, but in ground water somewhat higher. The concentration of bicarbonate is observed from 18.3 to $359.9 \mathrm{mg} / \mathrm{l}$, few samples exceeding the permissible limits of bicarbonate.

\section{Chloride $(\mathrm{Cl})$}

The chloride ion is the most predominant natural form of the element chlorine and is extremely stable in water. The chloride in groundwater may be from diverse sources such as weathering, leaching of sedimentary rocks and soil, domestic and municipal effluents (Sarath Prasanth et al. 2012). The range of chloride is found to vary between 115.21 and $2,011.8 \mathrm{mg} / \mathrm{l}$ for water samples. As per (World Health Organization 2011) and Indian standards (BIS, 1991) the desirable limit for chloride is $250 \mathrm{mg} / \mathrm{l}$. For the study area it has been found that in certain locations the chloride concentration exceeds the maximum permissible limit. The chloride ion concentration in groundwater of the study area exceeds the maximum allowable limit of $600 \mathrm{mg} / \mathrm{l}$ in two samples (2 and 11). They may be due to the lack of underground drainage system and bad maintenance of environment around the sources.

Sulphate $\left(\mathrm{SO}_{4}\right)$

The concentration of sulphate is likely to react with human organs if the concentration exceeds the maximum allowable limit of $400 \mathrm{mg} / \mathrm{l}$ and causes a laxative effect on human system with the excess magnesium in groundwater. The content of $\mathrm{SO}_{4}{ }^{-}$is observed from 22.2 to $98.6 \mathrm{mg} / \mathrm{l}$. However, the sulphate concentration in groundwater of the study area is within the maximum allowable limit in the entire sample. 


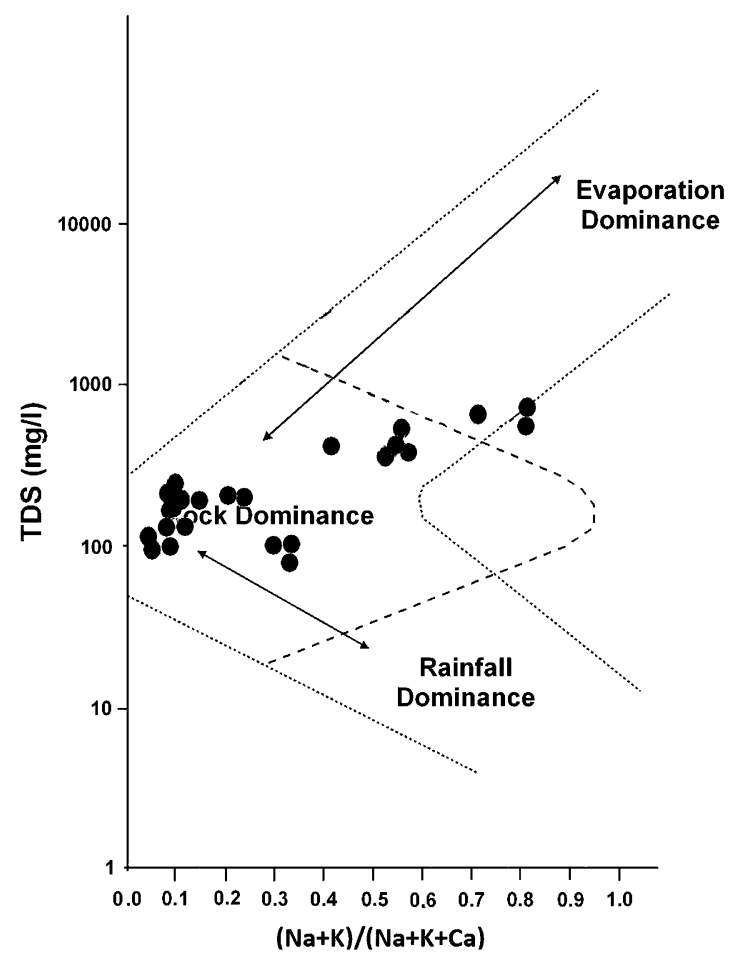

Fig. 2 Gibbs diagram

Nitrate $\left(\mathrm{NO}_{3}\right)$

Nitrogen compounds are the most widespread contaminants in subsurface environments, mainly originating from non-point and multi-point agricultural sources (Pang et al. 2013). Epidemiological evidence suggests that nitratenitrogen exposure is strongly associated with several diseases, such as methemoglobinemia (blue baby syndrome), gastric cancer, thyroid disease and diabetes (Krishna Kumar et al., 2011). Hence, increasing nitrogen contamination seriously threatens public drinking water supply and human health. The value of $\mathrm{NO}_{3}{ }^{-}$in the groundwater is observed between 0.1 and $3.9 \mathrm{mg} / \mathrm{l}$ with an average value of $1.01 \mathrm{mg} / \mathrm{l}$. All samples are not exceeding the permissible limit of $45 \mathrm{mg} / \mathrm{l}$ as per WHO standard.

Calcium and magnesium ( $\mathrm{Ca}$ and $\mathrm{Mg}$ )

The calcium and magnesium in waters are generally used to classify the suitability of water. Calcium and magnesium are directly related to hardness of the water and these ions are the most abundant elements in the surface and groundwater and exist mainly as bicarbonates and to a lesser degree in the form of sulphate and chloride. The concentration of $\mathrm{Ca}^{2+}$ is between 26 and $130 \mathrm{mg} / \mathrm{l}$, and concentration of $\mathrm{Mg}^{2+}$ is varied from 1.2 to $141.6 \mathrm{mg} / \mathrm{l}$. The maximum concentration of calcium ions can cause

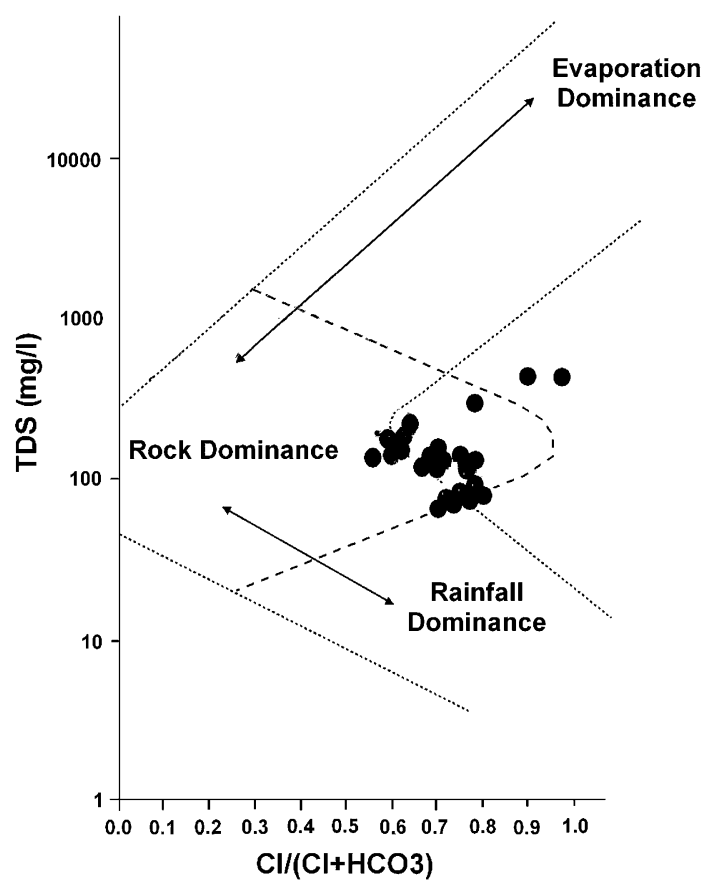

abdominal ailments and is undesirable for domestic purposes as it causes encrustation and scaling. The higher concentration of $\mathrm{Mg}^{2+}$ (66 and $141.6 \mathrm{mg} / \mathrm{l}$ ) is observed in the groundwater sample nos. 10 and 2. The rest of the groundwater samples show $\mathrm{Mg}^{2+}$ from 1.2 to $48 \mathrm{mg} / \mathrm{l}$. The contribution of $\mathrm{Ca}^{2+}$ and $\mathrm{Mg}^{2+}$ to the total cations is approximately 7 to $19 \%$ and 13 to $29 \%$, respectively.

Sodium and potassium ( $\mathrm{Na}$ and $\mathrm{K}$ )

The concentration of $\mathrm{Na}^{+}$is varied from 71 to $1,200 \mathrm{mg} / \mathrm{L}$. In general case, the $\mathrm{Na}^{+}$is the dominant ion among the cations and is present in most of the natural waters, which contributing approximately 53 to $69 \%$ of the total cations. This is because of the silicate weathering and/or dissolution of soil salts stored by the influences of evaporation, anthropogenic activities, agricultural activities and poor drainage conditions. The higher contribution of $\mathrm{Na}^{+}$than that of the contribution of $\mathrm{Ca}^{2+}$ to the total cations is expected due to influence of ion exchange. However, the higher concentration of $\mathrm{Na}^{+}$observed from the groundwater samples contributes approximately $73 \%$ to the total cations. $\mathrm{K}^{+}$is a naturally occurring element; but its concentration remains quite lower compared with $\mathrm{Ca}, \mathrm{Mg}$ and $\mathrm{Na}$. The average concentration of potassium is $9.33 \mathrm{mg} / \mathrm{l}$ and maximum value of $36 \mathrm{mg} / \mathrm{l}$, which indicate the potassium form complexes in studied conditions. 
Fig. 3 Piper trilinear diagram

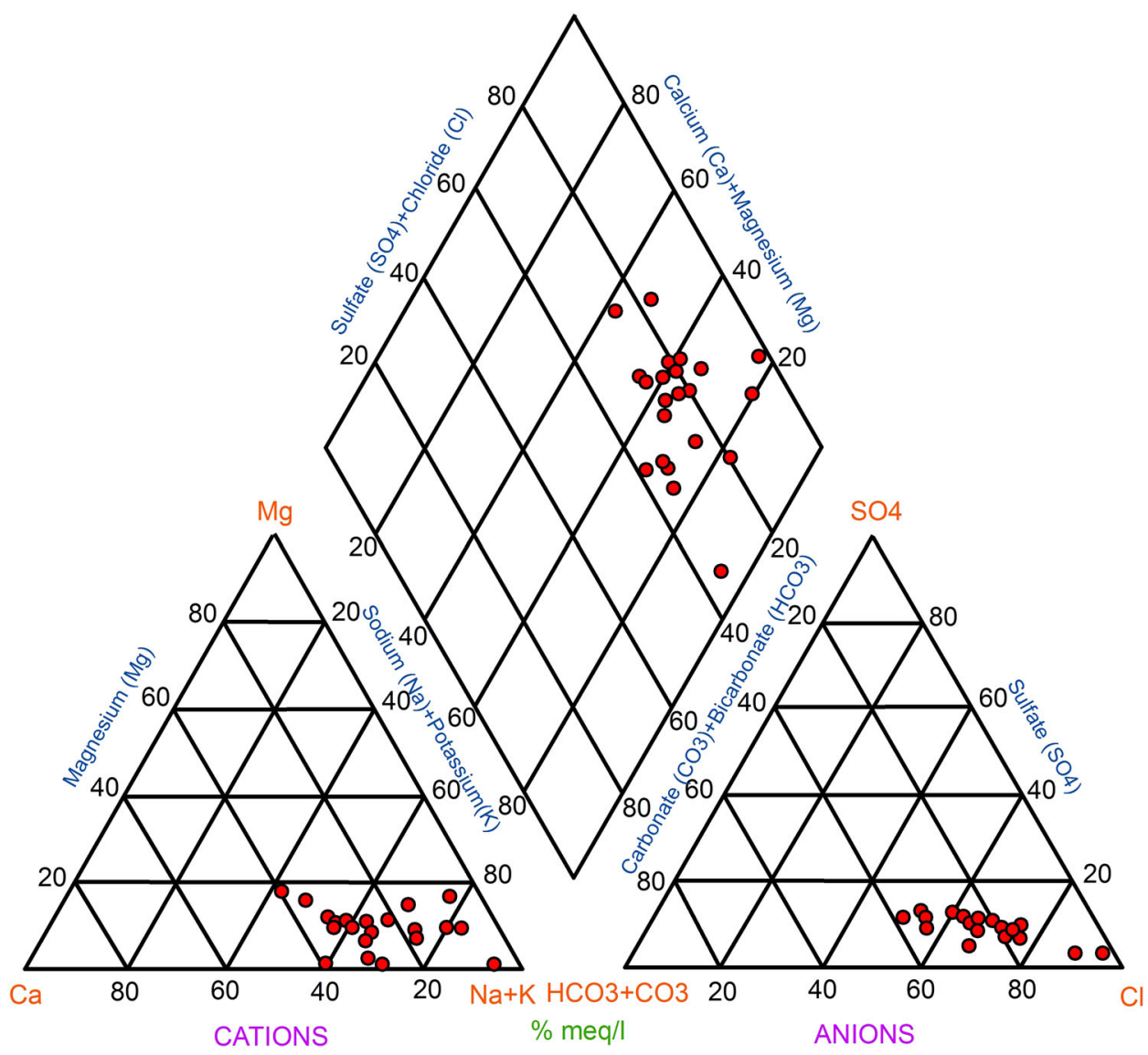

Table 2 Relative weight of chemical of physico-chemical parameters

\begin{tabular}{llll}
\hline $\begin{array}{l}\text { Chemical } \\
\text { parameters }\end{array}$ & $\begin{array}{l}\text { WHO } \\
\text { standards } \\
(2011)\end{array}$ & $\begin{array}{l}\text { Weight } \\
(w i)\end{array}$ & $\begin{array}{l}\text { Relative weight } \\
W i=w i / \sum_{i=1}^{n} w i\end{array}$ \\
\hline $\mathrm{pH}($ on scale) $)$ & $6.5-8.5$ & 4 & 0.114 \\
$\mathrm{EC}(\mu \mathrm{S} / \mathrm{cm})$ & 500 & 4 & 0.114 \\
$\mathrm{TDS}(\mathrm{mg} / \mathrm{l})$ & 500 & 5 & 0.142 \\
$\mathrm{HCO}_{3}(\mathrm{mg} / \mathrm{l})$ & 500 & 3 & 0.086 \\
$\mathrm{Cl}(\mathrm{mg} / \mathrm{l})$ & 250 & 3 & 0.086 \\
$\mathrm{SO}_{4}(\mathrm{mg} / \mathrm{l})$ & 250 & 4 & 0.114 \\
$\mathrm{NO}_{3}(\mathrm{mg} / \mathrm{l})$ & 45 & 5 & 0.142 \\
$\mathrm{Ca}(\mathrm{mg} / \mathrm{l})$ & 75 & 2 & 0.057 \\
$\mathrm{Mg}(\mathrm{mg} / \mathrm{l})$ & 50 & 1 & 0.029 \\
$\mathrm{Na}(\mathrm{mg} / \mathrm{l})$ & 200 & 2 & 0.057 \\
$\mathrm{~K}(\mathrm{mg} / \mathrm{l})$ & 200 & 2 & 0.057 \\
& & $\sum w i=35$ & $\sum w i=0.998$ \\
\hline
\end{tabular}

Total hardness $(\mathrm{TH})$

The classification of groundwater based on total hardness (TH) shows that a majority of the ground water samples

Table 3 Water quality classification ranges and types of water based on WQI values

\begin{tabular}{ll}
\hline Range & Type of water \\
\hline$<50$ & Excellent water \\
$50-100$ & Good water \\
$100-200$ & Poor water \\
$200-300$ & Very poor water \\
$>300$ & Water unsuitable for drinking purposes \\
\hline
\end{tabular}

fall in the hard water category. TH of the groundwater was calculated as suggested by Sawyer et al. 2003.

$\mathrm{TH}\left(\right.$ as $\left.\mathrm{CaCO}_{3}\right) \mathrm{mg}=\mathrm{Ca}^{2+}+\mathrm{Mg}^{2+}\left(\frac{\mathrm{meq}}{1}\right) \times 50$

The hardness values range from 89.5 to $814.55 \mathrm{mg} / \mathrm{l}$ with an average value of $211.59 \mathrm{mg} / \mathrm{l}$. The maximum allowable limit of $\mathrm{TH}$ for drinking purpose is $500 \mathrm{mg} / \mathrm{l}$ and the most desirable limit is $100 \mathrm{mg} / \mathrm{l}$ as per the WHO standard. Groundwater exceeding the limit of $300 \mathrm{mg} / \mathrm{l}$ is considered to be very hard. Sample nos. 2 and 11 exceed the maximum allowable limit of $500 \mathrm{mg} / \mathrm{l}$. The hardness of the water is due to the presence of alkaline earths such as calcium and magnesium. 
Table 4 Water quality index (WQI) classification for individual samples

\begin{tabular}{|c|c|c|}
\hline S No. & WQI values & Water quality classification type \\
\hline 1 & 53.69 & Good water \\
\hline 2 & 428.53 & Water unsuitable for drinking purposes \\
\hline 3 & 81.71 & Good water \\
\hline 4 & 48.63 & Excellent water \\
\hline 5 & 49.41 & Excellent water \\
\hline 6 & 44.28 & Excellent water \\
\hline 7 & 80.87 & Good water \\
\hline 8 & 80.47 & Good water \\
\hline 9 & 80.14 & Good water \\
\hline 10 & 226.75 & Very poor water \\
\hline 11 & 399.18 & Water unsuitable for drinking purposes \\
\hline 12 & 47.89 & Excellent water \\
\hline 13 & 92.18 & Good water \\
\hline 14 & 110.77 & Poor water \\
\hline 15 & 92.93 & Good water \\
\hline 16 & 101.30 & Poor water \\
\hline 17 & 135.88 & Poor water \\
\hline 18 & 48.54 & Excellent water \\
\hline 19 & 162.39 & Poor water \\
\hline 20 & 55.95 & Good water \\
\hline 21 & 50.54 & Good water \\
\hline 22 & 78.61 & Good water \\
\hline 23 & 84.25 & Good water \\
\hline 24 & 115.66 & Poor water \\
\hline
\end{tabular}

Gibbs diagram

Gibbs diagram is widely used to establish the relationship of water composition and aquifer lithological characteristics. Three distinct fields such as precipitation dominance, evaporation dominance and rock-water interaction dominance areas are shown in the Gibbs diagram (Gibbs, 1970). The predominant samples fall in the rock-water interaction dominance and evaporation dominance field of the Gibbs diagram (Fig. 2). The rock-water interaction dominance field indicates the interaction between rock chemistry and the chemistry of the percolated waters under the subsurface.

Gibbs ratio I (for anion) $=\frac{\mathrm{Cl}^{-}}{\left(\mathrm{Cl}^{-}+\mathrm{HCO}_{3}^{-}\right)}$

Gibbs ratio II (for cation $)=\frac{\mathrm{Na}^{+}+\mathrm{K}^{+}}{\left(\mathrm{Na}^{+}+\mathrm{K}^{+}+\mathrm{Ca}^{2+}\right)}$,

whereas all the ionic concentration is expressed in meq/l.

Piper trilinear diagram

Piper diagram is extensively used to understand problems concerning the geochemical evolution of groundwater.
This diagram consists of three distinct fields including two triangular fields and a diamond-shaped field. The cations expressed as percentage of total cations in meq/l as a single point on the left triangle while anions plot in the right triangle (Piper 1944). Each point is then projected into the upper field along a line parallel to the upper margin of the field and the point where the extension intersects indicates the character of the water as represented by the relationship among $\mathrm{Na}^{+}+\mathrm{K}^{+}, \mathrm{Ca}^{2+}+\mathrm{Mg}^{2+}, \mathrm{CO}_{3}{ }^{-}+\mathrm{HCO}_{3}{ }^{-}$and $\mathrm{Cl}^{-}, \mathrm{SO}_{4}{ }^{2-}$ ions. Similarities and differences among groundwater samples can be revealed from the trilinear diagram because water of similar qualities will tend to plot together as groups. Aquachem 4.0 scientific software is used for the plotting of piper trilinear diagram. The piper diagram is dominated by $\mathrm{NaCl}$ followed by mixed $\mathrm{CaMgCl}$ type facies (Fig. 3). This process indicates that alkalis $\left(\mathrm{Na}^{+}+\mathrm{K}^{+}\right)$and strong acids $\left(\mathrm{Cl}^{-}+\mathrm{SO}_{4}{ }^{2-}\right)$ dominated over the alkaline earth $\left(\mathrm{Ca}^{2+}+\mathrm{Mg}^{2+}\right)$ and weak acids. The elevated $\mathrm{Na}^{+}$concentrations coupled to low $\mathrm{Ca}^{2+}$ suggesting that $\mathrm{Ca}^{2+}$ and $\mathrm{Na}^{+}$ion exchange process is an important geochemical process for the $\mathrm{Na}-\mathrm{Cl}$ type of groundwater.

Water quality index calculation (WQI)

The chemistry of groundwater is often used as a tool for discriminating the drinking and irrigation water quality (Subba Rao 2006; Vasanthavigar et al. 2010). Water quality index (WQI) is an important parameter for identifying the water quality and its sustainability for drinking purposes (Subba Rao, 1997; Magesh et al. 2013). WQI is defined as a technique of rating that provides the composite influence of individual water quality parameters on the overall water quality (Mitra and ASABE Member 1998). (World Health Organization 2011) standards for drinking water quality have been used to calculate the WQI. The relative weight (wi) was assigned for water quality parameters based on their relative importance on water quality for drinking purposes (Table 2). The water quality classification based on WQI values is shown in Table 3. The calculation of WQI for groundwater samples is shown in Table 4. A total of 24 samples were analyzed for WQI. Among these, $20.83 \%$ of the samples showed excellent water, $45.83 \%$ of the samples fell under good water category, $20.83 \%$ of the samples showed poor water category, 4.16 and $8.33 \%$ of the samples fell under very poor water quality and water unsuitable for drinking purposes, respectively. This may be due to effective leaching and dissolution process of rock salt and gypsum-bearing rock formations. High concentration of EC, chloride, sodium followed by calcium clearly suggests that rock-water interaction process is the main source for degrading the water quality in the study area. 
Table 5 Correlation matrix $\left(\mathrm{r}_{2}\right)$ of studied physico-chemical parameters and major ions $(\mathrm{N}=24)$ of groundwater

\begin{tabular}{|c|c|c|c|c|c|c|c|c|c|c|c|c|c|}
\hline Parameters & Temp & $\mathrm{pH}$ & $\mathrm{EC}$ & TDS & $\mathrm{CO}_{3}$ & $\mathrm{HCO}_{3}$ & $\mathrm{Cl}$ & $\mathrm{SO}_{4}$ & $\mathrm{NO}_{3}$ & $\mathrm{Ca}$ & $\mathrm{Mg}$ & $\mathrm{Na}$ & $\mathrm{K}$ \\
\hline Temp & 1.000 & & & & & & & & & & & & \\
\hline $\mathrm{pH}$ & 0.244 & 1.000 & & & & & & & & & & & \\
\hline EC & -0.118 & 0.285 & 1.000 & & & & & & & & & & \\
\hline TDS & -0.118 & 0.285 & 1.000 & 1.000 & & & & & & & & & \\
\hline $\mathrm{CO}_{3}$ & 0.213 & 0.376 & 0.549 & 0.549 & 1.000 & & & & & & & & \\
\hline $\mathrm{HCO}_{3}$ & 0.013 & 0.605 & 0.255 & 0.255 & 0.076 & 1.000 & & & & & & & \\
\hline $\mathrm{Cl}$ & -0.125 & 0.158 & 0.952 & 0.952 & 0.471 & 0.114 & 1.000 & & & & & & \\
\hline $\mathrm{SO}_{4}$ & 0.131 & 0.536 & 0.777 & 0.777 & 0.454 & 0.601 & 0.638 & 1.000 & & & & & \\
\hline $\mathrm{NO}_{3}$ & 0.227 & 0.362 & 0.297 & 0.297 & -0.019 & 0.216 & 0.331 & 0.439 & 1.000 & & & & \\
\hline $\mathrm{Ca}$ & -0.240 & 0.179 & 0.727 & 0.727 & 0.134 & 0.215 & 0.767 & 0.454 & 0.296 & 1.000 & & & \\
\hline $\mathrm{Mg}$ & -0.053 & 0.087 & 0.894 & 0.894 & 0.545 & -0.107 & 0.872 & 0.565 & 0.231 & 0.621 & 1.000 & & \\
\hline $\mathrm{Na}$ & -0.117 & 0.311 & 0.964 & 0.964 & 0.663 & 0.256 & 0.892 & 0.759 & 0.170 & 0.636 & 0.838 & 1.000 & \\
\hline K & -0.117 & 0.190 & 0.966 & 0.966 & 0.604 & 0.090 & 0.924 & 0.687 & 0.255 & 0.639 & 0.903 & 0.960 & 1.000 \\
\hline
\end{tabular}

\section{Correlation matrix}

Statistical analysis was performed on the physico-chemical parameters and major ion concentration to detect the relationship and differences between the groundwater samples. In order to discuss the data, the values grouped with respect to the geochemical parameters. The average value of all the variables (temperature, $\mathrm{pH}$, EC, TDS, $\mathrm{CO}_{3}{ }^{-}, \mathrm{HCO}_{3}{ }^{-}, \mathrm{Cl}^{-}, \mathrm{SO}_{4}{ }^{2-}, \mathrm{NO}_{3}, \mathrm{Ca}^{2+}, \mathrm{Mg}^{2+}, \mathrm{Na}^{+}, \mathrm{K}^{+}$) determined and tabulated as matrix $(13 \times 24)$ in Table 5 . This matrix was analyzed with cluster analysis (hierarchical tree clustering, rescaled distance cluster combine analysis) using SPSS software (SPSS, 2001). The hierarchical cluster analysis was used to group water samples into significant clusters. The dendrogram analysis was performed using Ward method and the results of parameters are shown three groups in Fig. 4. Most of the samples were classified in group I and II with good correlation between $\mathrm{SO}_{4}, \mathrm{Ca}, \mathrm{HCO}_{3}, \mathrm{Cl}$ and $\mathrm{Na}$ with $\mathrm{EC}$ and TDS. The group III with one sub-group constructed with EC and TDS. The possible salt combinations $\left(\mathrm{CaSO}_{4}, \mathrm{NaCl}\right.$, and mixed $\mathrm{CaNaHCO}_{3}$ ) are probably derived from weathering of rock salts, gypsum-bearing aquifers and irrigation return flow. The concentration of nitrate is probably derived from anthropogenic activities. The water quality management can be implemented by proper removal/recycling of waste water and installation of sewage treatment plants.

\section{Conclusions}

The study area is always under stress due to increasing population and more demand for water resources. The hydrogeochemical analysis of the study reveals that the groundwater is fresh to brackish and moderately high to hard. The

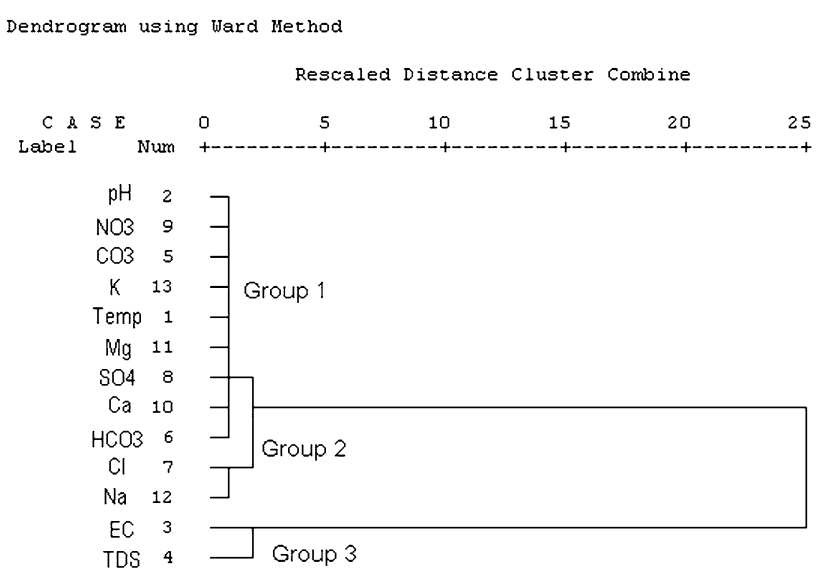

Fig. 4 Dendrogram for the groundwater grouping with respect to their physico-geochemical parameters

order of the abundance of the major cation and anion is as follows: $\quad \mathrm{Na}^{+}>\mathrm{Ca}^{2+}>\mathrm{Mg}^{2+}>\mathrm{K}^{+}=\mathrm{Cl}^{-}>\mathrm{H}$ $\mathrm{CO}_{3}{ }^{-}>\mathrm{SO}_{4}{ }^{2-}>\mathrm{CO}_{3}{ }^{2-}>\mathrm{NO}_{3}{ }^{2-}$. $\mathrm{Na}$ and $\mathrm{Cl}$ are dominant ions among the studied cations and anions. The concentration of potassium ion is within the permissible limit for drinking purpose except few locations. $20 \%$ of the groundwater samples have exceeded the permissible limit of sodium. Nitrate and sulphate ion concentrations are within the allowable limit for drinking purpose. Chloride, calcium and magnesium are within the allowable limit except few samples. According to Gibbs diagram, the predominant samples fall in the rock-water interaction dominance and evaporation dominance field. The piper trilinear diagram shows that groundwater in the study area is $\mathrm{Na}-\mathrm{Cl}$ and mixed $\mathrm{CaMgCl}$ type. Based on the WQI classification majority of the samples are falling under excellent to good water category and suitable for drinking water purposes. To improve the quality of water, the Government and non-government 
organization should provide the moral support to design the rain water harvesting structures and artificial recharge methods for young generation especially budding civil engineers.

Acknowledgments KK thanks Prof. Ramachandramoorthy, Vice Chancellor, St. Peters University and Prof. P. Partheeban, Dean Academic, St. Peters College of Engineering and Technology, Avadi, Chennai, for their kind support and provide the permission to publish this work.

Open Access This article is distributed under the terms of the Creative Commons Attribution License which permits any use, distribution, and reproduction in any medium, provided the original author(s) and the source are credited.

\section{References}

APHA (1995) Standard methods for the examination of water and wastewater, 19th edn. American Public Health Association, Washington, pp 1-467

Bagyaraj M, Ramkumar T, Venkatramanan S, Gurugnanam B (2013) Application of remote sensing and GIS analysis for identifying groundwater potential zone in parts of Kodaikanal Taluk, South India. Front Earth Sci 7(1):65-75

Ballukraya PN, Ravi R (1999) Characterisation of groundwater in the unconfined aquifer of Chennai city, India. J Geol Soc India 54:1-11

BIS (1991) (Bureau of Indian Standards) 10500 Indian Standard drinking water specification, 1 st rev, 1-8

CDSH (2012) Chennai district statistical handbook. District Administration, Chennai

Dixit S, Gupta SK, Tiwari S (2005) Nutrients overloading of a freshwater lake in Bhopal, India. Electron Green J 21:2-6

Gibbs RJ (1970) Mechanism controlling world water chemistry Sciences 170: 795-840

Hem JD (1985) Study and interpretation of the chemical characteristics of natural water: US Geological Survey Water-Supply Paper 2254, 3rd edn, 263

Jayaprakash M, Giridharan L, Venugopal S, Krishna Kumar SP, Periyakali P (2008) Characterization and evaluation of the factors affecting the geochemistry of groundwater in Neyveli, Tamil Nadu, India. Environ Geol 54(4):855-867

Jerry AN (1986) Basic environmental technology (water supply, waste disposal and pollution control). Wiley, New York

Krishna Kumar S, Chandrasekar N, Seralathan P, Godson PS, Magesh NS (2011) Hydrogeochemical study of shallow carbonate aquifers, Rameswaram Island, India. Environ Monit Assess 184(7):4127-4139

Magesh NS, Krishnakumar S, Chandrasekar N, Soundranayagam JP (2013) Groundwater quality assessment using WQI and GIS techniques, Dindigul district, Tamil Nadu, India. Arab J Geosci 6(11):4179-4189

Malini S, Nagaiah N, Paramesh L, Venkataramaiah P, Balasubramanian A (2003) Groundwater quality around Mysore, Karnataka, India. Int J Environ Stud 60:87-98
Mitra BK, ASABE Member (1998) Spatial and temporal variation of ground water quality in sand dune area of Aomori Prefecture in Japan

Padmalal D, Maya K, Narendra Babu K, Baiju RS, Babura B (2012) Hydro chemical characterization and water quality assessment of the coastal springs of southern Kerala, India. J Appl Geochem 14(4):466-481

Pang Z, Yuan L, Huang T, Kong Y, Liu J, Li Y (2013) Impacts of human activities on the occurrence of groundwater nitrate in an alluvial plain: a multiple isotopic tracers approach. JEarth Sci 24(1):111-124

Piper AM (1944) A graphical interpretation of water-analysis. Trans Am Geophys Union 25:914-928

Raju NJ, Shukla UK, Ram P (2011) Hydrogeochemistry for the assessment of groundwater quality in Varanasi: a fast-urbanizing center in Uttar Pradesh, India. Environ Monit Assess 173:279-300

Reddy PM, Subba Rao N (2001) Effect of industrial effluents on the groundwater regime in Vishakhapatnam. Pollut Res 20(3):383-386

CGWB Technical Report (2008) District groundwater brochure Chennai district Tamil Nadu. pp 1-19

Sarath Prasanth SV, Magesh NS, Jitheshlal KV, Chandrasekar N (2012) Evaluation of groundwater quality and its suitability for drinking and agricultural use in the coastal stretch of Alappuzha District, Kerala, India. Appl Water Sci 2(3):165-175

Sawyer GN, McCartly DL, Parkin GF (2003) Chemistry for environmental engineering and science, 5th edn. McGraw Hill, New York, p 752

Selvam S, Manimaran G, Sivasubramanian P (2013) Hydrochemical characteristics and GIS-based assessment of groundwater quality in the coastal aquifers of Tuticorin corporation, Tamilnadu, India. Appl Water Sci 3:145-159

SPSS (2001) SPSS for Windows, Rel. 11.0.1. 2001. Chicago: SPSS Inc

Srinivas Y, Hudson Oliver D, Stanley Raj A, Chandrasekar N (2013) Evaluation of groundwater quality in and around Nagercoil town, Tamil Nadu, India: an integrated geochemical and GIS approach. Appl Water Sci 3:631-651

Subba Rao N (1997) Studies of water quality index in hard rock terrain of Guntur district, Andra Pradesh, India. In: National Seminar on Hydrology of Precambrian Terrains and hard rock areas, $129-134$

Subba Rao N (2006) Seasonal variation of groundwater quality in a part of Guntur district, Andhra Pradesh, India. Environ Geol 49:413-429

Tiwari KK, Prasad RN, Chandra Ram, Mondal NC (2012) Geochemical parameters for assessment of groundwater quality around urban and suburban areas of Dausa city in Rajasthan, India. J Appl Geochem 14(2):184-193

Todd DK (1980) Groundwater hydrology. Wiley, New York

Vasanthavigar M, Srinivasamoorthy K, Vijayaragavan K, Rajiv Ganthi R, Chidambaram S, Anandhan P, Manivannan R, Vasudevan S (2010) Application of water quality for groundwater quality assessment: Thirumanimuttar Sub basin, Tamil Nadu, India. Environ Monit Assess 171(1-4):595-609

WHO (2011) WHO Guidelines for Drinking-water Quality, fourth ed. World Health Organization 